Красинский Владислав Вячеславович

доктор юридических наук, член Общественного

консультативного научно-методического Совета

при ЦИК России

\title{
О соотношении понятий «оперативно-розыскная деятельность» и «оперативно-разыскная деятельность»
}

Аннотация: В статье анализируются терминологические аспекты оперативно-розыскной деятельности. Автор изучает правовое регулирование и толкование оперативно-розыскной деятельности в Российской Федерации.

Ключевые слова: оперативно-розыскная деятельность, оперативно-розыскные мероприятия, правоохранительные органы, спецслужбы, сыск.

The article examines the terminological aspects of investigatory activity. The author studies the legal regulation and interpretation of investigatory activity in Russian Federation.

Key words: investigatory activity, investigatory measures, law enforcement agencies, special services, criminal investigation.

Красинский В.В. О соотношении понятий «оперативно-розыскная деятельность» и «оперативноразыскная деятельность»// Современное право. 2012. № 8; www.krasinskiy.ru

В последние несколько лет все большие масштабы приобретает несогласованность в правовом регулировании и толковании терминологического аспекта оперативно-розыскной деятельности, проводимой уполномоченными государственными органами Российской Федерации. Анализ правовых актов свидетельствует о наличии значительного числа нормативных документов, в которых упоминаются «оперативно-розыскная деятельность» и «оперативнорозыскные мероприятия», с одной стороны (Федеральные законы от 03.04.1995 г. № 40-Ф3 «О федеральной службе безопасности», от 15.07.1995 г. № 103-Ф3 «О содержании под стражей подозреваемых и обвиняемых в совершении преступлений», от 12.08.1995 г. № 144-Ф3 «Об оперативно-розыскной деятельности», от 10.01.1996 г. № 5-Ф3 «О внешней разведке», от 27.05.1996 г. №57-Ф3 «О государственной охране», от 27.05. мая 1998 г. № 76-Ф3 «О статусе военнослужащих», от 25.07.1998 г. № 128-Ф3 «О государственной дактилоскопической экспертизе», от 24.06.1999 г. № 120-Ф3 «Об основах системы профилактики безнадзорности и правонарушений несовершеннолетних», от 31.05 .2002 г. № 63-Ф3 «Об адвокатской деятельности и адвокатуре в Российской Федерации», от 07.07.2003 г. № 126-Ф3 «О связи», от 20.08.2004 г. № 119-Ф3 «О государ- 
ственной защите потерпевших, свидетелей и иных участников уголовного судопроизводства», от 27.06.2006 г. № 152-Ф3 «О персональных данных», от 03.12.2008 г. № 242-Ф3 «О государственной геномной регистрации в Российской Федерации», от 27.11.2010 г. № 311-Ф3 «О таможенном регулировании в Российской Федерации»), и «оперативно-разыскная деятельность» в сочетании с «оперативно-разыскными мероприятиями», с другой (Федеральные законы от 25.12.2008 г. № 273-Ф3 «О противодействии коррупции», от 07.02.2011 г. № 3Ф3 «О полиции», от 07.02.2011 г. № 7-Ф3 «О клиринге и клиринговой деятельности», от 01.07.2011 г. № 170-Ф3 «О техническом осмотре транспортных средств и о внесении изменений в отдельные законодательные акты Российской Федерации», от 21.11.2011 г. № 325-Ф3 «Об организованных торгах», Указ Президента Российской Федерации от 30.11.1995 г. № 1203 «Об утверждении перечня сведений, отнесенных к государственной тайне», Постановление Правительства Российской Федерации от 27.08.2005 г. № 538 «Об утверждении Правил взаимодействия операторов связи с уполномоченными государственными органами, осуществляющими оперативно-разыскную деятельность») ${ }^{1}$. В органах по контролю за оборотом наркотических средств и психотропных веществ, органах внутренних дел, органах федеральной службы безопасности созданы оперативно-разыскной департамент, управление координации оперативно-разыскной деятельности, управление оперативно-разыскной информации, управление организации оперативно-разыскной деятельности, оперативноразыскное управление, межрегиональные оперативно-разыскные отделы (отделения), оперативно-разыскные части².

С чем связана подобная двойственность? Вольное обращение с правовыми категориями и искажение формулировок Федерального закона осуществлялись в ряде случаев в угоду ведомственным интересам (подгонка наименований правовых актов под названия оперативных подразделений, субъективные тре-

${ }^{1}$ Предметом статьи не является лингвистический анализ терминологии оперативнорозыскной деятельности.

${ }^{2}$ В ФТС России действуют оперативно-розыскные отделы оперативных таможен и 
бования руководства отдельных правоохранительных органов к ведению делопроизводства, недостатки в работе правотворческих органов и органов юстиции при принятии и регистрации ведомственных нормативных правовых актов, регулирующих оперативно-розыскную деятельность, и др.)‥ Постепенно законы и ведомственные акты, регулирующие оперативно-розыскную деятельность, приспособили под нужды конкретных чиновников в погонах.

Казалось бы, что страшного? Разница в одной букве. Но сложившаяся ситуация не настолько проста. Данная проблема выходит за рамки юридической техники и герменевтики.

Во-первых, для обозначения одних и тех же понятий недопустимо использовать различные термины² ${ }^{2}$.

Во-вторых, недопустимо без веских оснований отказываться от ранее используемой терминологии ${ }^{3}$.

В-третьих, несоответствие юридической терминологии применительно к оперативно-розыскной деятельности может привести к неправовому ограничению конституционных прав граждан и нарушению законности в деятельности государственных органов.

Защита и создание условий для реализации прав и свобод человека и гражданина является обязанностью государства. В статье 55 Конституции Российской Федерации отмечено, что права и свободы человека и гражданина могут быть ограничены только федеральным законом. В Российской Федерации действует Федеральный закон от 12 августа 1995 г. № 144-Ф3 «Об оперативнорозыскной деятельности», в котором закреплены задачи и принципы оператив-

оперативно-розыскные отделения таможен.

${ }^{1} \mathrm{~B}$ соответствии с Федеральным законом «Об оперативно-розыскной деятельности» перечень дел оперативного учета и порядок их ведения, а также организация и тактика проведения оперативно-розыскных мероприятий определяются нормативными актами органов, осуществляющих оперативно-розыскную деятельность. Данные правовые акты предусматривают механизм реализации Федерального закона «Об оперативно-розыскной деятельности».

${ }^{2}$ Алексеев С.С. Общая теория права. М.: Проспект, 2008. С. 488.

${ }^{3}$ Пиголкин А.C. Юридическая терминология и пути ее совершенствования // Ученые 
но-розыскной деятельности, перечень оперативно-розыскных мероприятий, система гарантий законности при их проведении. Поэтому деятельность, которая ограничивает конституционные права и свободы человека и гражданина, не предусмотренная федеральным законом, порождает правовые последствия, аналогичные незаконным действиям государственных органов и их должностных лиц, нарушающим права и свободы граждан.

Российское законодательство предусматривает проведение только оперативно-розыскной деятельности и оперативно-розыскных мероприятий. Правомерность оперативно-розыскной деятельности и соответствующих мероприятий подтверждена Определением Конституционного Суда Российской Федерации от 14 июля 1998 года № 86-О «По делу о проверке конституционности отдельных положений Федерального закона «Об оперативно-розыскной деятельности» по жалобе гражданки И.Г.Черновой», Определением Конституционного Суда Российской Федерации от 20 октября 2005 г. № 375-О «Об отказе в принятии к рассмотрению жалобы гражданина Макаренко А.М. на нарушение его конституционных прав ч.4 ст. 29 УПК РФ и статьями 6-9 Федерального закона «Об оперативно-розыскной деятельности», Определением Конституционного Суда Российской Федерации от 24 января 2006 г. № 27-О «Об отказе в принятии к рассмотрению жалобы гражданина Киштыкова Д.К. на нарушение его конституционных прав статьей 9 Федерального закона «Об оперативнорозыскной деятельности», Определением Конституционного Суда Российской Федерации от 8 февраля 2007 г. № 128-О-П «Об отказе в принятии к рассмотрению жалобы гражданина Мартиросяна О.Б. на нарушение его конституционных прав статьей 9 Федерального закона «Об оперативно-розыскной деятельности», Определением Конституционного Суда Российской Федерации от 29 мая 2007 г. № 417-О-О «Об отказе в принятии к рассмотрению жалобы гражданина Иванова К.В. на нарушение его конституционных прав статьями 15 и 17 Федерального закона «Об оперативно-розыскной деятельности» и статьями 48 
и 49 Федерального закона «О наркотических средствах и психотропных веществах», Постановлением Конституционного Суда Российской Федерации от 9 июня 2011 г. № 12-П «По делу о проверке конституционности положений пункта 7 статьи 16 Закона Российской Федерации «О статусе судей в Российской Федерации» и части 1 статьи 9 Федерального закона «Об оперативнорозыскной деятельности» в связи с жалобой гражданина И.В. Аносова» ${ }^{.}$

Оперативно-розыскные мероприятия осуществляются специально уполномоченными субъектами (в настоящее время - органами внутренних дел, органами федеральной службы безопасности, органами государственной охраны, органами по контролю за оборотом наркотических средств и психотропных веществ, таможенными органами, оперативными подразделениями Службы внешней разведки, Федеральной службы исполнения наказаний, органа внешней разведки Министерства обороны) с соблюдением установленного порядка и при наличии законных оснований на их проведение. Полученные таким образом результаты оперативно-розыскной деятельности могут использоваться для возбуждения уголовных дел, представляться в орган дознания, следователю или в суд, а также использоваться в доказывании по уголовным делам². И наоборот, не предусмотренная Федеральным законом «Об оперативно-розыскной деятельности» деятельность не может служить основой для формирования доказательной базы при осуществлении уголовного судопроизводства. В соответствии с частью 2 статьи 50 Конституции Российской Федерации при осуществлении правосудия не допускается использование доказательств, полученных с нару-

${ }^{1}$ Рос. газ. 1998. 11 августа; Конституционное правосудие в странах СНГ и Балтии. 2007. № 12; Конституционное правосудие в странах СНГ и Балтии. 2007. № 22; Рос. газ. 2011. 22 июня.

${ }^{2}$ Статья 89 Уголовно-процессуального кодекса Российской Федерации, Определение Конституционного Суда Российской Федерации от 11 июля 2006 г. № 268-О «По жалобе гражданина Уразова С.В. на нарушение его конституционных прав положениями статей 49, 91, 227, 228, 229, 255 и 355 УПК РФ и статей 6, 8 и 10 Федерального закона «Об оперативнорозыскной деятельности», Приказ МВД России, ФСБ России, ФСО России, ФТС, СВР России, ФСИН, ФСКН и МО РФ от 17 апреля 2007 г. № 368/185/164/481/32/184/97/147 «ОБ утверждении Инструкции о порядке представления результатов оперативно-розыскной деятельности дознавателю, органу дознания, следователю, прокурору или в суд». 
шением федерального закона. Такие доказательства признаются не имеющими юридической силы и не подлежат использованию при производстве дознания и предварительного следствия, а также при разбирательстве уголовных дел в суде.

Одной из важнейших гарантий, призванных защитить права и свободы граждан от произвольного и чрезмерного их ограничения органами и должностными лицами, осуществляющими оперативно-розыскную деятельность, является предварительный судебный контроль за законностью и обоснованностью оперативно-розыскных мероприятий. Статья 9 Федерального закона «Об оперативно-розыскной деятельности» устанавливает основания и порядок судебного рассмотрения материалов об ограничении конституционных прав граждан на тайну переписки, телефонных переговоров, почтовых, телеграфных и иных сообщений, передаваемых по сетям электрической и почтовой связи, на неприкосновенность жилища при проведении оперативно-розыскных мероприятий.

Граждане и организации вправе обжаловать незаконную «оперативноразыскную» деятельность спецслужб и правоохранительных органов и потребовать взыскания необходимой компенсации нанесенного вреда за нарушения прав человека и гражданина на неприкосновенность частной жизни, личную и семейную тайну, защиту чести и доброго имени, неприкосновенность жилища и тайну переписки, телефонных переговоров, почтовых отправлений, телеграфных и иных сообщений. Виновные должностные лица могут быть привлечены к ответственности.

Деятельность, ограничивающая конституционные права и свободы человека и гражданина, не предусмотренная федеральным законом или нарушающая его, является преступной в соответствии с Уголовным кодексом Российской Федерации. Уголовный кодекс Российской Федерации содержит несколько составов преступлений, связанных с незаконным сбором или распространением информации под предлогом выявления, предупреждения, пресечения и 
раскрытия преступлений, розыска лиц и сбора сведений об угрозах безопасности государства и общества. К числу подобных преступлений, совершаемых должностными лицами (сотрудниками правоохранительных органов, работниками почты, телеграфа и телефонных станций), отнесены: нарушение неприкосновенности частной жизни (ст. 137 УК РФ); нарушение тайны переписки, телефонных переговоров, почтовых, телеграфных или иных сообщений (ст. 138 УК РФ); нарушение неприкосновенности жилища (ст. 139 УК РФ).

Ошибочное использование словосочетаний «оперативно-разыскная деятельность» и «оперативно-разыскные мероприятия» влечет за собой целый ряд негативных последствий. Осуществление правоохранительными органами и спецслужбами пресловутой оперативно-разыскной деятельности может нанести ущерб законной оперативно-розыскной практике. Любой квалифицированный защитник поставит под сомнение одновременное наличие в Российской Федерации правовых режимов оперативно-розыскной и «оперативно-разыскной» деятельности, правомерность оснований и законность результатов оперативной деятельности, не предусмотренной Федеральным законом «Об оперативнорозыскной деятельности», и обжалует подобную деятельность государства в отношении своих подзащитных (подзащитного) в суде. Предметом проверки в судах общей юрисдикции могут стать соблюдение определенного Федеральным законом «Об оперативно-розыскной деятельности» перечня оперативнорозыскных мероприятий; законность и обоснованность проведения «оперативно-разыскных мероприятий», в том числе тех, разрешения на проведение которых даны судом; наличие оснований, соблюдение установленных условий, порядка и сроков проведения «оперативно-разыскных мероприятий».

В целях создания дополнительных гарантий законности при осуществлении оперативно-розыскной деятельности нужно свести к минимуму ведомственную практику решения вопросов оперативно-розыскной деятельности в частном порядке, признать допущенные ошибки и провести скорейшую работу по их исправлению. В связи с этим предлагается: 
- Федеральному Собранию Российской Федерации провести анализ федеральных законов, регламентирующих оперативно-розыскную деятельность уполномоченных субъектов, связанных с ними законодательных актов, и привести их в соответствие с Федеральным законом «Об оперативно-розыскной деятельности».

- На основании Приказа Генеральной прокуратуры Российской Федерации от 15 февраля 2011 года № 33 «Об организации прокурорского надзора за исполнением законов при осуществлении оперативно-розыскной деятельности» Генеральной прокуратуре Российской Федерации провести проверку правовой регламентации оперативно-розыскной деятельности в части ведомственного правотворчества и правоприменения уполномоченных на ее проведение субъектов. При реализации надзорных полномочий особое внимание обратить на соответствие «оперативно-разыскных мероприятий» целям и задачам оперативно-розыскной деятельности, соблюдение определенного Федеральным законом «Об оперативно-розыскной деятельности» перечня оперативно-розыскных мероприятий, соблюдение конституционных прав и свобод человека и гражданина в ходе осуществления «оперативно-разыскной деятельности».

- Субъектам правотворчества, исказившим положения Федерального закона «Об оперативно-розыскной деятельности» надлежит привести содержание своих подзаконных актов в соответствие с требованиями данного Федерального закона. Предлагается проверить деятельность уполномоченных подразделений и должностных лиц аппаратов правотворческих органов в части проведения лингвистической экспертизы проектов нормативных правовых актов и правового мониторинга качества ведомственного нормотворчества.

- Судам общей юрисдикции рекомендуется усилить судебный контроль за оперативно-розыскной деятельностью субъектов, уполномоченных на ее проведение, в том числе законности и обоснованности проведения «оперативноразыскных мероприятий», разрешения на проведение которых даются судами. 
- Структурные подразделения (оперативные аппараты), проводящие оперативно-разыскную деятельность и оперативно-разыскные мероприятия, представляется целесообразным переименовать в соответствии с Федеральным законом «Об оперативно-розыскной деятельности».

Научный подход к основным категориям сыска, дальнейшие теоретикоправовые исследования законодательных и подзаконных актов, касающихся оперативно-розыскной деятельности, будут способствовать совершенствованию правового регулирования оперативно-розыскной деятельности, формированию профессионального правопонимания руководителей и оперативных сотрудников уполномоченных государственных органов, осуществляющих оперативно-розыскную деятельность.

Красинский Владислав Вячеславович доктор юридических наук, член Общественного консультативного научно-методического Совета при ЦИК России 